\title{
最近の蒾学
}

\section{3. 歯科材料}

床用レジンの新乾熱重合法とその装置

現在床用レジンの重合には殆んど湯浴による湿式重合 法が採られているが，もつと合理的な方法として考案し たのが、ここに紹介する新乾熱重合法とその装置であ る。

增原, 田中" (1962) は餅状レジンの重合硬化のメカニ ズムを研究した結果, 餅状レジンは加熱された部分から 重合硬化し，気泡もそれにつれて消隇してゅくことを知 つた。

また架橋鼡の配合が気泡の消滅に効果のあることも知 つた。

これらの知見を基礎として乾熱法で気泡のないレジン 床を重合する方法を確立したものである。

新乾熱重合法の概要

新乾熱重合法は油圧プレス機と電熱式加熱板を組合せ たサーモブレス機を用いて餅状レジンを加熱重合する方 法である。

この方法はフラスコに油压のプレスをかけた状態で，

フラスコの底面からのみ加熱することを特徴としている

フラスコの底面から一方的に熱を伝えるために，餅状 レジンは粘膜面から徐々に重合が進み、レジンの重合収 縮は床の表面(研磨する面)一出ることになる。また気泡 もこの過程で逐次消滅してゅき，気泡のないレジン床が できる。

この方法で電通したレジン床は従来の湯浴で重合した 場合よりも変形が少く，床と粘膜面の適合度がよい。

実験の結果 ${ }^{2}$ ，この方法で重合したレジンのキカイ的 な強さは, 20 分間の通電で最大に達し, 従来の湿式法よ

りも短時間で十分な重合ができることがわかつた。

この方法の利点を次にまとめて㧍こう。

1）寸法精度のよい，気泡のないレジン床が製作でき る。

2）レジンの重合時間が短縮され，作が半自動的とな り能率的である。

3）重合中にプレスが追加できるだけでなく，重合中 つねにプレスが効いている(従来のハンドプレス では死圧となる)。

4）湯浴式では水蒸気が発生したが，それだだく技工 室の環境が改善される。

次に試作されたサーモプレス機の仕様を示してお く。

1) 大きさ：高さ $45 \mathrm{~cm}$, 間口 $30 \mathrm{~cm}$, 奥行 $16 \mathrm{~cm}$ で $\begin{array}{lllll}\text { 材研 } & \text { 有機 } & \text { 増 原 } & \text { 英 一 } \\ \text { 補緅 } & \text { 原 } & \text { 田 } & \text { 義 雄 }\end{array}$

技工台の上に設置できる。

2）加圧装置：上部にハンドプレスがあり，フラスコ を締めた後，下から油圧でプレス寸る。 フラスコに加える 総圧力は約 $1,500 \mathrm{~kg}$ 程度であ る。な㧍過圧のときは安全弁が作動する。

3）加熱装置：上下に $300 \mathrm{~W}$ 電熱板が装着してあり フラスコ 1 コの場合は下の電熱板のみ通電し，フ ラスコ $2 \beth$ の場合は上・下に通電する。

通電時間は夕イムスイッチでコントロールするが，夏 期 10 分間, 冬期 20 分間の通電でレジンが重合される。 フラスコは加圧したまま放冷した後取り出す。

なお常温重合レジンを使用する場合，本装置を使用す れば冬期でも 3 分間程度の通電で所期の目的を達するこ とができるので便利である。

1）增原，田中：歯科理工誌，1，1（1962）。

2) 增原，原田：歯科理工誌，5，9（1964）。

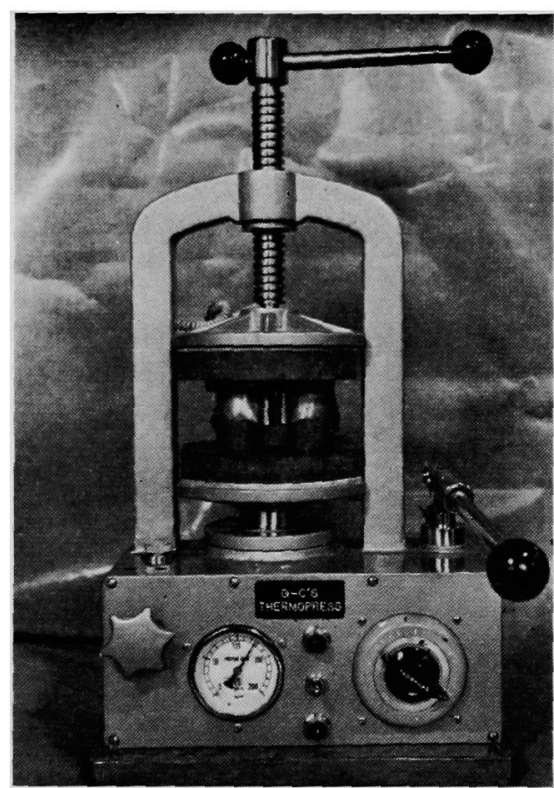

新乾熱重合法のための装置（試作） 